$\mathbb{T}$ periodica polytechnica

Chemical Engineering $53 / 1$ (2009) 37

doi: 10.3311/pp.ch.2009-1.01

web: http://www.pp.bme.hu/ch

(c) Periodica Polytechnica 2009

RESEARCH ARTICLE

\section{Catalytic Co-Processing of delayed coker light naphtha with other refinery gasoline streams}

\author{
Attila Lengyel / Szabolcs Magyar / Jenó Hancsók
}

Received 2008-01-23

\begin{abstract}
Upgrading of delayed coker light naphtha is very difficult due to its high diolefin and silicon content. Mixtures of light straight run naphtha and delayed coker light naphtha fractions were hydrotreated in two stages over $\mathrm{NiMo} / \mathrm{Al}_{2} \mathrm{O}_{3}$ and $\mathrm{CoMo} / \mathrm{Al}_{2} \mathrm{O}_{3}$ catalysts (diolefin saturation followed by hydrodesulphurization ). The results showed that naphtha fractions free of diolefins, olefins, sulphur and silicon can be produced with the two stage hydrogenation. These are excellent feeds for naphtha isomerization. One-stage selective hydrodesulphurization tests were also conducted with blends of coker naphtha (up to 5 vol\%) and fluid catalytic crackers gasoline over $\mathrm{CoMo} / \mathrm{Al}_{2} \mathrm{O}_{3}$. Diolefinfree products of $<10 \mathrm{mg} / \mathrm{kg}$ sulphur could be produced with a research octane number loss of max. 3.
\end{abstract}

\section{Keywords}

coker naphtha $\cdot H D S \cdot$ silicon $\cdot$ diolefin saturation

\section{Attila Lengyel}

Szabolcs Magyar

Hungrana Ltd., H-2432 Szabadegyháza, Hungary

\section{Jenő Hancsók}

Department of Hydrocarbon and Coal Processing, Pannon University, H-8201 Veszprém, P.O. Box 158, Hungary

\section{Introduction}

Increasingly higher fraction of the heavy and residual oil needs to be converted into valuable hydrocarbon stocks (gasoline, Jet fuel, gas oils, lube oils, etc.). The significance of residue conversion technologies has been increasing in the past decade with delayed coking being one of the most wide-spread ones. Integration of delayed coker light naphtha (DCLN) into the processing structure of a petroleum refinery is very difficult due to its composition (0.4-2\% sulphur; 40-400 ppmw nitrogen; 1-2\% diolefins; $35-45 \%$ olefins).

Very few papers were published about the upgrading of coker naphthas. There are basically three options: A) injection of DCLN into the riser of fluid catalytic cracking unit (FCC) unit [1]-[2], B) selective diolefin saturation/Si adsorption prior to hydrodesulphurization (HDS), C) co-processing of the DCLN with FCC gasoline.

HDS of DCLN is a great challenge. Conjugated diolefins polymerise at normal HDS conditions, and the polymers cause fouling of the reactor resulting in pressure drop build-up. In addition, degradation products of the silicone oil (poly-dimethylsiloxane) used as anti-foam additive in delayed coking is a threat to the catalysts of the downstream technologies [3]. Loss of activity is irreversible and cannot be restored by catalyst regeneration.

DCLN may also be upgraded together with FCC gasoline in HDS unit. Most of the refineries have already started up their units of selective FCC gasoline HDS (minimized olefin saturation, moderate research octane number loss). There are quite a number of studies [4]-[7] on the selective HDS of FCC gasoline itself but much less information is available about the coprocessing of coker naphtha with FCC gasoline.

In this work mixtures of DCLN and light straight run naphtha (LSRN) (up to $20 \%$ DCLN) were hydrotreated in two steps to saturate diolefins (first step; $\mathrm{NiMo} / \mathrm{Al}_{2} \mathrm{O}_{3}$ ) and to convert heteroatoms containing compounds $\left(\mathrm{CoMo} / \mathrm{Al}_{2} \mathrm{O}_{3}\right)$, respectively. Effect of reaction temperature on diolefin saturation, silicon uptake and HDS were investigated. Experiments were also carried out with mixtures of DCLN (up to 5 vol\%) and FCC gasoline. 


\section{Experimental}

\subsection{Hydrocarbon feedstocks}

Properties of the feedstocks are given in Table 1 DCLN was blended into LSRN cut produced from Russian crude oil in the Atmospheric Distillation Unit of the Danube Refinery, Százhalombatta, Hungary. FCC gasoline was produced in the same refinery. The majority of the DCLN sulphur was present in the form of mercaptans.

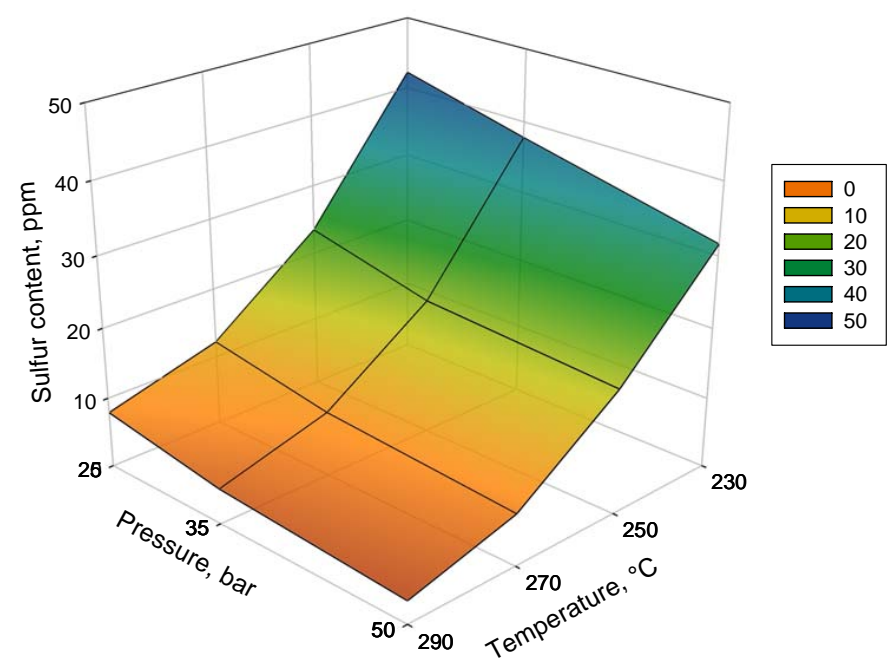

Fig. 1. Effect of temperature and pressure on the sulphur content of the products $(\mathrm{LHSV}=2.0)$

\subsection{Catalysts}

Commercially available catalysts were used both in the diolefin saturation step $\left(\mathrm{NiMo} / \mathrm{Al}_{2} \mathrm{O}_{3} ; \mathrm{MoO}_{3}: 19.5 \mathrm{wt} \%\right.$; $\mathrm{NiO}: 4.0$ wt\%; nominal diameter: 1.15-1.35; average length: $2.5 \mathrm{~mm}$; loading density: $\left.680 \mathrm{~kg} / \mathrm{m}^{3}\right)$ and in the HDS step $(\mathrm{CoMo} / \gamma$ $\mathrm{Al}_{2} \mathrm{O}_{3}$ average diameter; $1.3 \mathrm{~mm}$; specific area: $218 \mathrm{~m}^{2} / \mathrm{g}$; pore volume: $0.4 \mathrm{~cm}^{3} / \mathrm{g}$; Mo content: $11.2 \%$, cobalt content $3.1 \%$ ). Co-processing of DCLN with FCC gasoline was carried out over a special $\mathrm{CoMo} / \mathrm{Al}_{2} \mathrm{O}_{3}$ (selective FCC gasoline HDS catalyst).

\subsection{Hydrotreating pilot unit}

The tests were carried out in continuous operation in a pilot hydrotreating unit. The effective volume of the HDS reactor is $100 \mathrm{~cm}^{3}$. The test system contained all the equipments and devices (pumps, separators, heat exchanger as well as temperature, pressure and gas flow controllers), which are applied in full-scale commercial naphtha hydrotreaters.

\subsection{Methods}

Compositions of feedstocks, liquid and vapour phase products were determined by gas chromatography according to a modified version of NF M07-086 method [8]. Octane numbers were calculated from the compositions using CARBURANE software. Sulphur and nitrogen contents were measured according to ISO 20846 and ASTM-D 6366-99, respectively.

\subsection{Process conditions}

Process conditions for two-step upgrading of DCLN-LSRN blends:

- Diolefin saturation: $\mathrm{T}=120-190^{\circ} \mathrm{C} ; \mathrm{P}=20$ bar; liquid hourly space velocity (LHSV): $4.0 ; \mathrm{H}_{2} / \mathrm{HC}: 80 \mathrm{Nm}^{3} / \mathrm{m}^{3}$

- HDS: $\mathrm{T}=310-320^{\circ} \mathrm{C} ; \mathrm{P}=20$ bar; LHSV: $6.0 ; \mathrm{H}_{2} / \mathrm{HC}: 80$ $\mathrm{Nm}^{3} / \mathrm{m}^{3}$

Process conditions for selective HDS of DCLN-FCC naphtha blend:

- $\mathrm{T}=220-290^{\circ} \mathrm{C} ; \mathrm{P}=25-50$ bar; LHSV: 2.0-5.0; $\mathrm{H}_{2} / \mathrm{HC}: 150$ $\mathrm{Nm}^{3} / \mathrm{m}^{3}$

\section{Results and discussion}

\subsection{Diolefin saturation step of two-step hydrogenation of DCLN/LSRN blends}

Results of the diolefin saturation carried out over commercial $\mathrm{NiMo} / \mathrm{Al}_{2} \mathrm{O}_{3}$ are summarized in Table 2 Diolefin conversion was high even at $120^{\circ} \mathrm{C}$. With the increase of temperature, diolefin content of the products decreased. Diolefin-free interim products were produced at $180^{\circ} \mathrm{C}$ and $190^{\circ} \mathrm{C}$. Conversion of mono-olefins was very low, which is advantageous in terms of heat control through the catalyst bed. Rate of HDS was minor at the mild conditions of the first step. (Deep HDS is not required at this stage) Silicon content was completely adsorbed on the $\mathrm{NiMo} / \mathrm{Al}_{2} \mathrm{O}_{3}$ catalyst at $180^{\circ} \mathrm{C}-190^{\circ} \mathrm{C} .180^{\circ} \mathrm{C}-190^{\circ}$ was the optimal for diolefin saturation, since both diolefin conversion and silicon uptake took place efficiently. In order to suppress olefin saturation and control the heat of reaction, further increase of temperature is not beneficial. The catalyst is able to adsorb the silicon compounds without loss of catalyst activity. Normally, cycle length of hydrotreating catalysts is 3-5 years. Afterwards, the catalysts are generally regenerated ex-situ. This catalyst has high silicon uptake capacity, silicon break-through does not occur before scheduled catalyst replacement at the end of catalysts cycle.

After finding the proper temperature of diolefin saturation, sample collection was performed with the blend containing 10 wt $\%$ DCLN ( $+90 \mathrm{wt} \% \mathrm{LSRN}$ ) at $190^{\circ} \mathrm{C}$ reaction temperature to produce feed for the HDS step. The product was practically free of diolefins and silicon and its sulphur content was about 300 $\mathrm{mg} / \mathrm{kg}$. Copper strip corrosion rating was class $2 \mathrm{c}$. Corrosivity was caused by the sulphur compounds originating from DCLN. The relatively low temperature and dilution of diolefin content with diolefin-free straight run naphtha ensured that there was no coke formation on the catalyst bed.

\subsection{HDS step of the two-step hydrogenation of DCLN/LSRNblend}

Experimental results of the HDS step are summarized in Table 3 The tests were carried out at reactor inlet temperatures of $300^{\circ} \mathrm{C}, 305^{\circ} \mathrm{C}$ and $310^{\circ} \mathrm{C}$. Product properties were very similar 
at all three reaction temperatures. Sulphur content of the products was below $2.5 \mathrm{mg} / \mathrm{kg}$ and their nitrogen content was decreased below $1.5 \mathrm{mg} / \mathrm{kg}$. Copper strip corrosion test was also satisfactory: 1A (best quality class). Concentration of olefins was reduced from $4.3 \mathrm{wt} \%$ to $0.3 \mathrm{wt} \%$. Deep olefin saturation is very advantageous in this case because it enables downstream skeletal isomerization of the product to manufacture a high quality isomerate with excellent octane number. Residual unsaturated hydrocarbons in the product are C7 olefins and 1octene (Separation of the lab-scale distillation was not satisfactory). Content of aromatics was practically unchanged.

Summarized, after diolefin saturation and HDS the DCLN, which was blended into Russian light straight-run naphtha, can be directed to light naphtha isomerization, since it is free of silicon, sulphur and nitrogen.

\subsection{One-step selective HDS of DCLN/FCC gasoline blends over $\mathrm{CoMo} / \mathrm{Al}_{2} \mathrm{O}_{3}$}

DCLN was blended into FCC gasoline in 5 vol\% (feed "C"). Blend ratio was adjusted to match the volume flow of the refinery streams. Selective HDS of this blend was investigated over a commercial selective FCC gasoline HDS catalyst (new generation $\mathrm{CoMo} / \mathrm{Al}_{2} \mathrm{O}_{3}$ ). Under proper process conditions sulphur content of the feed $(525 \mathrm{mg} / \mathrm{kg}$ ) could be reduced below 10 $\mathrm{mg} / \mathrm{kg}$. No yield loss due to hydrocracking was observed.

Fig. 1 shows the sulphur content of the final products in function of reaction temperature and pressure at $L H S V=2.0$. The highest rate of $\mathrm{HDS}$ was $93.7 \%$ at $290^{\circ} \mathrm{C}$.

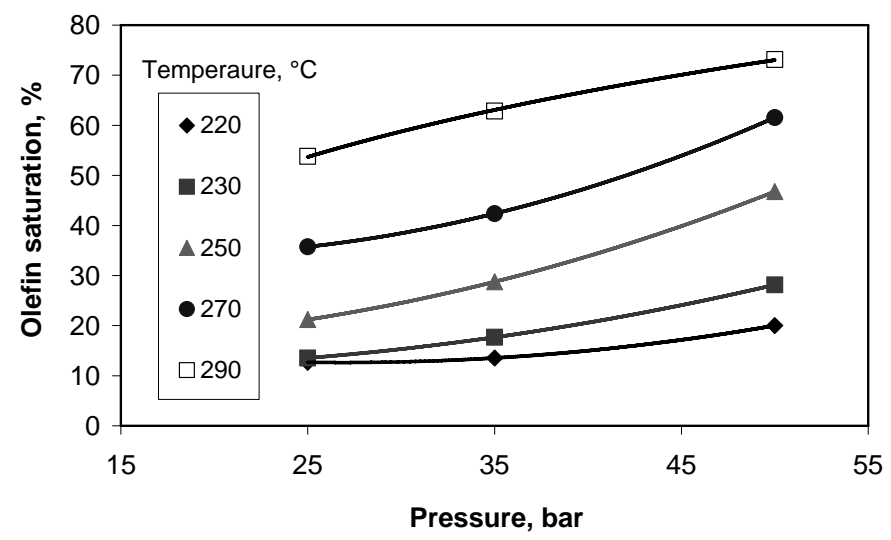

Fig. 2. Effect of pressure on olefin saturation at various temperatures $(\mathrm{LHSV}=2.0)$

A sulphur level of $10 \mathrm{mg} / \mathrm{kg}$ was achieved with the following process conditions: temperature $270-290^{\circ} \mathrm{C}$; pressure: $25-35$ bar; LHSV: 2.0-3.0; $\mathrm{H}_{2} / \mathrm{HC}: 150 \mathrm{Nm}^{3} / \mathrm{m}^{3}$.

Hydrodenitrogenation (HDN) was less efficient compared to sulphur removal. Nitrogen content of the products could not be reduced below $14 \mathrm{mg} / \mathrm{kg}$ even at the most severe process conditions. As an example, Fig. 4 shows the nitrogen content of the products vs. reaction temperature at a pressure of 25 bar. The increase of pressure has minor effect on the rate of HDN. For

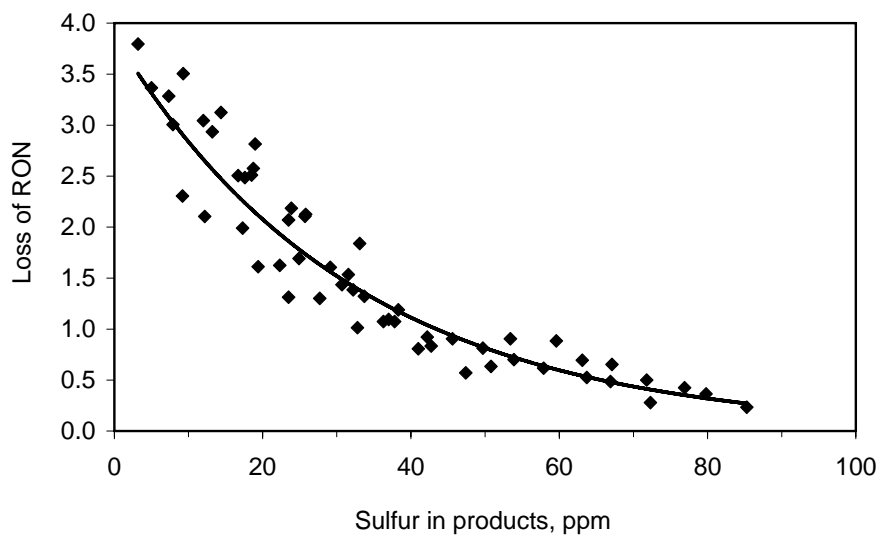

Fig. 3. Loss of RON vs. sulphur content of the products

Tab. 1. Main characteristics of hydrocarbons cuts

\begin{tabular}{|c|c|c|c|}
\hline \multirow{3}{*}{ Characteristics } & \multicolumn{3}{|c|}{ Hydrocarbon feedstocks } \\
\hline & ,A” & „B” & „C" \\
\hline & $\begin{array}{l}10 \% \text { DCLN+ } \\
90 \% \text { LSRN }\end{array}$ & $\begin{array}{c}20 \% \text { DCLN+ } \\
80 \% \text { LSRN }\end{array}$ & $\begin{array}{c}5 \% \text { DCLN + } \\
95 \% \text { FCC } \\
\text { gasoline }\end{array}$ \\
\hline Density $\left(15^{\circ} \mathrm{C}\right), \mathrm{g} / \mathrm{cm}^{3}$ & 0.675 & 0.684 & \\
\hline Sulphur content, mg/kg & 433 & 746 & 525 \\
\hline Nitrogen content, mg/kg & 8 & 15.8 & 35 \\
\hline Silicon content, mg/kg & 69 & 140 & \\
\hline $\begin{array}{l}\text { Bromine number, } \\
\mathrm{g} \mathrm{Br} / 100 \mathrm{~g}\end{array}$ & 11 & 18 & \\
\hline Average molecular weight & 81.74 & 81.17 & 94.7 \\
\hline \multicolumn{4}{|l|}{ HC composition, wt $\%$} \\
\hline naphthenes & 20.25 & 18.28 & 9.2 \\
\hline paraffins & 72.98 & 71.87 & 37.4 \\
\hline olefins & 5.41 & 8.69 & 23.2 \\
\hline aromatics & 1.36 & 1.16 & 30.2 \\
\hline \multicolumn{4}{|l|}{$\begin{array}{l}\text { Diolefin composition, } \\
\text { wt\% }\end{array}$} \\
\hline isoprene & 0.03 & 0.06 & 0.046 \\
\hline 1-trans-3-pentadien & 0.05 & 0.09 & 0.047 \\
\hline 1,3-cyclopentadien & 0.00 & 0.00 & 0.00 \\
\hline 1-cis-3-pentadien & 0.04 & 0.07 & 0.041 \\
\hline 2,3-pentadien & 0.01 & - & 0.002 \\
\hline total $\mathrm{C}_{5}$ diolefins & 0.13 & 0.22 & 0.136 \\
\hline \multicolumn{4}{|l|}{ Simulated distillation } \\
\hline $\mathrm{IBP},{ }^{\circ} \mathrm{C}$ & -6 & -6 & 2 \\
\hline $10 \%,{ }^{\circ} \mathrm{C}$ & 23 & 23 & 24 \\
\hline $30 \%,{ }^{\circ} \mathrm{C}$ & 36 & 36 & 62 \\
\hline $50 \%,{ }^{\circ} \mathrm{C}$ & 61 & 61 & 98 \\
\hline $70 \%,{ }^{\circ} \mathrm{C}$ & 75 & 75 & 116 \\
\hline $90 \%,{ }^{\circ} \mathrm{C}$ & 94 & 93 & 188 \\
\hline $95 \%,{ }^{\circ} \mathrm{C}$ & 103 & 98 & 206 \\
\hline $\mathrm{FBP},{ }^{\circ} \mathrm{C}$ & 118 & 117 & 232 \\
\hline
\end{tabular}

example, if the pressure is raised from 25 to 50 bar at a temperature of $220^{\circ} \mathrm{C}$ and LHSV of 2.0 , the difference in the nitrogen content of the products is only about $2 \mathrm{mg} / \mathrm{kg}$. 
Tab. 2. Effect of temperature on product properties in the diolefin sauration step

\begin{tabular}{|c|c|c|c|c|c|c|c|c|c|c|}
\hline \multirow{2}{*}{$\begin{array}{l}\text { Characteristics } \\
\text { DCLN in feed, wt\% }\end{array}$} & \multicolumn{10}{|c|}{ Naphtha products after diolefin saturation over $\mathrm{NiMo} / \mathrm{Al}_{2} \mathrm{O}_{3}$} \\
\hline & 10 & 20 & 10 & 20 & 10 & 20 & 10 & 20 & 10 & 20 \\
\hline Temperature, ${ }^{\circ} \mathrm{C}$ & 120 & 120 & 140 & 140 & 160 & 160 & 180 & 180 & 190 & 190 \\
\hline $\begin{array}{l}\text { Density }\left(15^{\circ} \mathrm{C}\right) \\
\mathrm{g} / \mathrm{cm}^{3}\end{array}$ & 0.6768 & 0.6773 & 0.6769 & 0.6774 & 0.6766 & 0.6794 & 0.6777 & 0.6777 & 0.6773 & 0.6777 \\
\hline Sulphur, mg/kg & 387 & 697 & 365 & 679 & 358 & 635 & 342 & 607 & 288 & 603 \\
\hline Nitrogen, $\mathrm{mg} / \mathrm{kg}$ & 7.4 & 13.8 & 7.3 & 12.7 & 6.5 & 12.4 & 6.5 & 11.8 & 6.2 & 11.5 \\
\hline Silicon, mg/kg & 68 & 139 & 59 & 132 & 46 & 119 & $<1$ & 8.8 & $<1$ & 3.8 \\
\hline $\begin{array}{l}\text { Bromine number, } \\
\mathrm{g} \mathrm{Br} / 100 \mathrm{~g}\end{array}$ & 11.1 & 18.0 & 11.4 & 17.8 & 10.6 & 19.3 & 10.1 & 16.8 & 10.0 & 16.8 \\
\hline Dien value, g l/100g & 0.29 & 0.63 & 0.21 & 0.20 & 0.16 & 0.13 & 0.00 & 0.00 & 0.00 & 0.00 \\
\hline Average MW & 82.21 & 82.04 & 82.19 & 82.09 & 82.17 & 82.12 & 82.17 & 81.91 & 82.05 & 81.95 \\
\hline naphthenes & 20.92 & 20.48 & 20.92 & 20.76 & 20.91 & 20.83 & 20.87 & 20.31 & 21.12 & 20.40 \\
\hline paraffins & 72.95 & 69.78 & 73.45 & 69.90 & 72.08 & 72.42 & 72.94 & 70.56 & 73.32 & 70.43 \\
\hline olefins & 4.80 & 8.33 & 4.30 & 7.91 & 5.68 & 5.40 & 4.90 & 7.83 & 4.29 & 7.83 \\
\hline aromatics & 1.32 & 1.41 & 1.32 & 1.43 & 1.34 & 1.32 & 1.28 & 1.31 & 1.27 & 1.33 \\
\hline \multicolumn{11}{|l|}{ Diolefin content, wt\% } \\
\hline isoprene & 0.02 & 0.02 & 0.00 & 0.00 & 0.00 & 0.00 & 0.00 & 0.00 & 0.00 & 0.00 \\
\hline 1-trans-3-pentadien & 0.03 & 0.05 & 0.03 & 0.00 & 0.01 & 0.01 & 0.00 & 0.00 & 0.00 & 0.00 \\
\hline 1,3-cyclopentadien & 0.00 & 0.00 & 0.00 & 0.00 & 0.00 & 0.00 & 0.00 & 0.00 & 0.00 & 0.00 \\
\hline 1-cis-3-pentadien & 0.03 & 0.04 & 0.03 & 0.02 & 0.01 & 0.01 & 0.00 & 0.00 & 0.00 & 0.00 \\
\hline 2,3-pentadien & 0.01 & 0.01 & 0.00 & 0.01 & 0.01 & 0.01 & 0.00 & 0.00 & 0.00 & 0.00 \\
\hline total $\mathrm{C}_{5}$ diolefins & 0.09 & 0.12 & 0.06 & 0.03 & 0.03 & 0.03 & 0.00 & 0.00 & 0.00 & 0.00 \\
\hline
\end{tabular}

Tab. 3. Properties of hydrotreated DCLN/LSRN naphthas after HDS step

\begin{tabular}{lcccc}
\hline Characteristics & Feed of HDS step & \multicolumn{3}{c}{ Naphtha products after HDS step } \\
\hline Inlet temperature, ${ }^{\circ} \mathrm{C}$ & - & 300 & 305 & 310 \\
Max bed temperature, ${ }^{\circ} \mathrm{C}$ & - & 308 & 316 & 319 \\
Density $\left(15^{\circ} \mathrm{C}\right), \mathrm{g} / \mathrm{cm}^{3}$ & 0.6765 & 0.6775 & 0.6767 & 0.6772 \\
Sulphur, $\mathrm{mg} / \mathrm{kg}$ & 288 & $<2.5$ & $<2.5$ & $<2.5$ \\
Nitrogen, $\mathrm{mg} / \mathrm{kg}$ & 6.2 & $<1.5$ & $<1.5$ & $<1.5$ \\
Silicon, $\mathrm{mg} / \mathrm{kg}$ & $<1$ & $<1$ & $<1$ & $<1$ \\
Copper strip corrosion class & $2 \mathrm{C}$ & $1 \mathrm{~A}$ & $1 \mathrm{~A}$ & $1 \mathrm{~A}$ \\
\hline HC composition, wt\% & & & & \\
naphthenes & 21.12 & 21.07 & 21.05 & 20.95 \\
paraffins & 73.32 & 77.24 & 77.39 & 77.39 \\
olefins & 4.29 & 0.32 & 0.28 & 0.31 \\
aromatics & 1.27 & 1.37 & 1.27 & 1.35 \\
\hline Aromatics composition, wt\% & & & & 0.62 \\
benzene & 0.62 & 0.61 & 0.61 & 0.65 \\
toluene & 0.57 & 0.66 & 0.61 & 0.09 \\
ethyl-benzene & 0.01 & 0.09 & 0.02 & \\
\hline
\end{tabular}




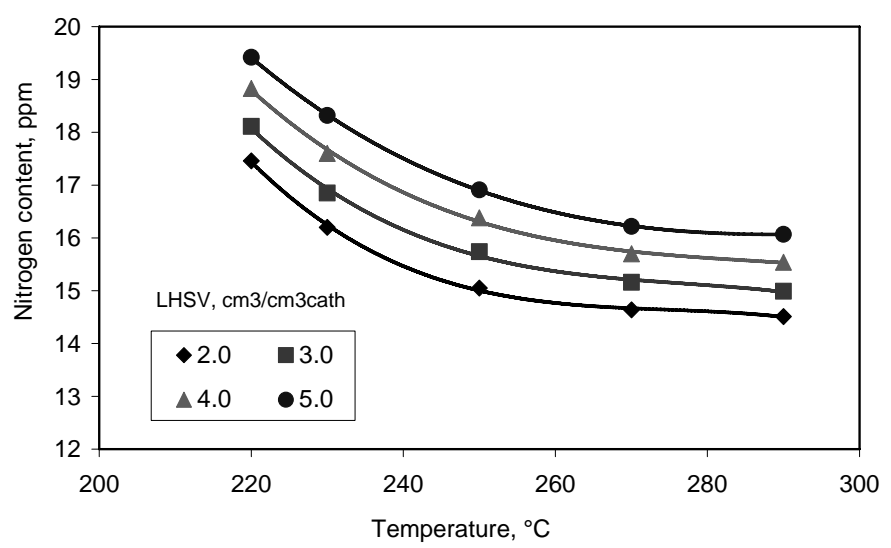

Fig. 4. Nitrogen content of the products as a function of temperature and LHSV

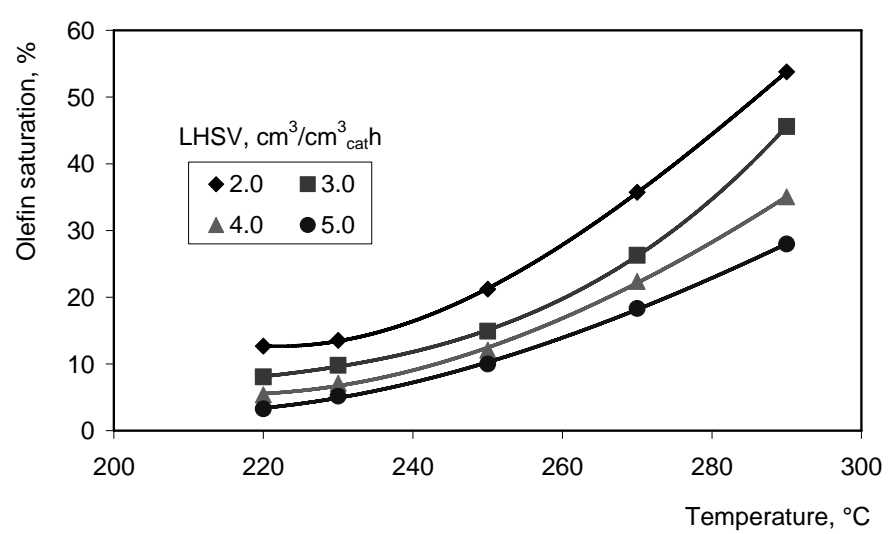

Fig. 5. Olefin saturation as a function of temperature and LHSV (pressure: 25 bar)

Fig. 5] shows the olefin saturation as a function of temperature and LHSV at a pressure of 25 bar. The olefin saturation was moderate when the pressure was only 25 bar, as the values were in the interval of $3.3-53.8 \%$. The same values for pressures of 35 and 50 bar are 5.2-62.8\% and 5.5-73.1\%, respectively.

The pressure had more significant effect on olefin saturation at higher temperatures (Fig. 2). For example, at a temperature of $220^{\circ} \mathrm{C}$ and LHSV of 2.0, a pressure increase of 25 bar resulted in only $15.4 \%$ increase of olefin saturation, while this value was $25.9 \%$ at a temperature of $270^{\circ} \mathrm{C}$.

The loss of research octane number $(\mathrm{RON})$ varied between 0.2-3.0 at a pressure of 25 bar and between 0.6-3.8 at a pressure of 50 bar. Considering a product sulphur level of about 10 $\mathrm{mg} / \mathrm{kg}$, the loss of research octane number is about 2.3-3.5 units (Fig. 3).

Although the diolefin saturation step was omitted, diolefins were completely removed; they could not be detected in the products by gas chromatography (GC) . After three-weeks of pilot test runs the reactor of the pilot unit was dismantled and the top layer of the catalyst bed was visually observed. No sign of significant gum formation or coke formation was observed, neither any sign of corrosion. In another test runs carried out with DCLN alone, excessive coke formation and strong corro- sion was observed in the inert ceramic packing bed above the catalyst layer.

\section{Summary}

Blends of DCLN and LSRN were hydrotreated in two steps (diolefin saturation and silicon removal with $\mathrm{NiMo} / \mathrm{Al}_{2} \mathrm{O}_{3}$, followed by HDS and olefin saturation over $\mathrm{CoMo} / \mathrm{Al}_{2} \mathrm{O}_{3}$ ). Optimal temperature of diolefin saturation was found to be 180$190^{\circ} \mathrm{C}$, which ensured both high diolefin conversion and efficient silicon removal while minimized undesired gum formation. After the HDS step, silicon-, sulphur-, nitrogen and olefin-free hydrocarbon fraction was produced, which is an excellent feedstock for light naphtha isomerisation.

A selective FCC gasoline HDS catalyst was used to upgrade a blend of DCLN and FCC gasoline (5\% and $95 \%$, respectively). The loss of RON was 2.3-3.0 units at $10 \mathrm{mg} / \mathrm{kg}$ product sulphur level. The following process conditions seem to be favourable for max. HDS and min. olefin saturation: $\mathrm{T}=290^{\circ} \mathrm{C}, \mathrm{P}=25 \mathrm{bar}$; $\mathrm{LHSV}=2.0$ or $\mathrm{T}=270^{\circ} \mathrm{C} ; \mathrm{P}=35$ bar; $\mathrm{LHSV}=2.0$.

\section{References}

1 Fernandez ML, Lacelle A, Bilbao J, Arandes JM, Recycling Hydrocarbon Cuts into FCC Units, Energy and Fuels 16 (2002), 615-621, DOI 10.1021/ef010184i.

2 Torre I, Arandes JM, Azkoiti MJ, Olazar M, Bilbao J, Cracking of Coker Naphtha With Gas-Oil. Effect of HZSM-5 Zeolit Addition to the Catalysts, Energy and Fuels 21 (2007), 11-18, DOI 10.1021/ef060344w.

3 Breivik R, Egebjerg R, Novel Coker Naphtha Hydrotreating Technology, ERTC 12th Annual Meeting (2007).

4 Magyar Sz, Hancsók J, Kalló D, Reactivity of Several Olefins in the HDS of full boiling point range FCC gasoline over PtPd/USY, Fuel Processing Technology 89 (2008), 736-739.

5 Miller JT, Reagen WJ, Kadluk JA, Marshall CL, Kropf AJ, Selective Hydrodesulphurization of FCC Naphtha with Supported MoS $\mathrm{S}_{2}$ Catalysts: The Role of Cobalt”, Journal of Catalysis 193 (2000), 23-131, DOI 10.1006/jcat.2000.2873.

6 Toba M, Miki Y, Kanda Y, Matsui T, Harada M, Yoshimura Y, Selective Hydrodesulphurization of FCC Gasoline over CoMo/Al ${ }_{2} \mathrm{O}_{3}$ Sulfide Catalyst, Catalysis Today 104 (2005), 64-69, DOI 10.1016/j.cattod.2005.03.027.

7 Yin C, Zhao R, Liu C, Selectively Hydrodesulphurization of FCC Naphtha over Monolayer Dispersion Catalysts, Petroleum Science and Technology 21 (2003), 1617-1624, DOI 10.1081/LFT-120023242.

8 Darouich T, Behar F, Largeau C, Budzinski H, Separation and Characterisation of the C15-Aromatic Fraction of Safaniya Crude Oil, Oil and Gas Science and Technology-Rev. IFP 60 (2005), no. 4, 681-695. 